\title{
PREDICTION OF FUTURE LAND USE LAND COVER CHANGES OF KELANTAN, MALAYSIA
}

\author{
M. A. Mahamud ${ }^{1, *}$, N. Samat ${ }^{1}$, M. L. Tan ${ }^{1}$, N. W. Chan ${ }^{1}$, Y. L. Tew ${ }^{1}$ \\ ${ }^{1}$ School of Humanities, Universiti Sains Malaysia, 11800 Minden, Penang, Malaysia - (amirul.phdusm, yilintew)@gmail.com, \\ (narimah, mouleong, nwchan)@usm.my
}

\begin{abstract}
KEY WORDS: CA-Markov, Cellular Automata, Geographical Information System, Urban Spatial Growth, Sustainable Development.
\end{abstract}

\begin{abstract}
:
Land use land cover change (LULC) is a dynamic process, which is largely influenced by anthropogenic effect. In less urbanized area, human activities such as agricultural expansion, timber extraction and infrastructure development, has caused LULC transformation at alarming rate. Understanding of the potential future LULC changes is necessary for town planners and local authorities to formulate and design town planning. Besides that, the projected LULC patterns could also be incorporated into other models to further evaluate the impact of LULC changes on environment, agricultural, ecosystem, water resources and health. This study projected a future LULC scenario of Kelantan, Malaysia, using an integrated GIS CA-Markov model. The model achieved an accuracy of $78.57 \%$ when compared with the LULC map of 2008. Built-up area has increased by $111 \mathrm{~km}^{2}$, while forest area has decreased $1532 \mathrm{~km}^{2}$ in the past 15 years. Results showed that the built-up area, oil palm, and rubber plantation are expected to increase to $181.69 \mathrm{~km}^{2}, 2142.48 \mathrm{~km}^{2}$, and $3076.24 \mathrm{~km}^{2}$, respectively, in 2025 . By contrast, forest and paddy area are projected to decrease to $8548.20 \mathrm{~km}^{2}$, and $693.44 \mathrm{~km}^{2}$ respectively. Urban expansion is mainly found in the northern part of the state, while oil palm expansion in the southern part of the state. It was predicted that this pattern will continue in the next thirty years where built-up and agriculture area continued to expand at the stake of forest area. The findings provide useful information for planners in planning for future development and safeguarding the environment.
\end{abstract}

\section{INTRODUCTION}

Rapid increasing of human population, along with the knowledge and technologies development resulted the largescale changes in land use land cover (LULC) around the world. LULC plays a vital role in the terrestrial ecosystem biodiversity, water resources, climate system and socio-economic sectors. Analysis of the spatio-temporal changes in LULC is therefore becoming one of the core research topics in the last few decades. For example, the LULC change program initiated by National Aeronautics and Space Administration (NASA) aims to pull together the LULC research activities and to help scientific community be aware the most up-to-date trends in this field.

In general, LULC is closely related with the surrounding environment. Any significant changes in LULC could affect the regional quality of ecological environment (Chu et al., 2018). Many studies have been conducted to study the impact of LULC changes on the environment such as water resources (Tan et al., 2015; Li et al., 2018) and ecosystem services (Sharma et al., 2019). For instance, Jodar-Abellan et al. (2019) found that the LULC changes increase the flash flood risk in five Mediterranean watersheds in Spain. More frequent and intense floods could lead to a large impact on socio-economic sector. Hence, sustainable development of LULC is essential to reduce the LULC changes impact on the environment.

LULC is a dynamic process that occurs across time and space. To understand that process, various tools have been developed. For example, Geographic Information System (GIS) and remote sensing have been integrated with spatial models to describe and simulate land use land cover transformation (Batty \& Xie, 1994; Samat \& Mahamud, 2018). CA-Markov, for example, has become a popular dynamic model used in forecasting urban systems (Samat, 2009). The study by Omar et al. (2014) investigated historical transformation of Kirkuk City, Iraq. That study used an integrated multi-regression and multicriteria evaluation approach as CA transition rules to simulate urban land use land cover changes from 1984 to 2010. Similarly, the study by Liping et al. (2018) also predicted spatial pattern of LULC in Jiangle China from 1992 to 2014 and predicted future LULC pattern for 2025 and 2035. That study managed to use CA-Markov to provide suggestion and become a basis for urban development planning of Jiangle County, China. Wang et al. (2018) applied the CA-Markov model to simulate three scenarios of environmental protection, crop protection and spontaneous in Tianjin city, China, in 2025 and 2035. They reported the spontaneous scenario would lead to the highest built-up area increment in the city.

In Malaysia, Samat (2009) used GIS and CA-Markov to model urban development in Seberang Perai, Penang. Transition rule was developed based on land suitability analysis. Similarly, Samat \& Mahamud (2018) modeled the urban transformation of George Town Conurbation, Malaysia, based on the originally developed model by Samat (2009). Those studies showed that GIS and CA-Markov has the ability to model land use land cover transformation and can be used as planning tool to simulate future development scenarios.

Kelantan is a state of Malaysia that frequently affected by monsoon floods. The big yellow flood event in the end of 2014 had brought a huge impact to the local population (Tan et al., 2018). Malaysian government was then allocated a special fund to study he flood event. Various impact assessment studies have been conducted in Kelantan in the aspects of ground water quality (Sheikhy-Narany et al., 2017), water resources (Tan et 
al., 2017), etc. However, incorporation of future land use land cover projections is still rarely reported due to the limited of future LULC projections for this region. It application in forecasting LULC for Kelantan State will be beneficial to control deforestation in the state.

This study aims to develop a reliable LULC projection for the Kelantan state. Specific objectives are (1) to validate the reliability of CA-Markov model in projecting the historical LULC maps; and (2) to project a future LULC map of the Kelantan state in 2025 using an integrated GIS and CA-Markov. The projected LULC map could be used for urban planners and local authorities to make better decisions in land use related plans and policies. Moreover, the LULC projections can be incorporated into any hydrological, flood, socio-economic, ecological models to further analyse the potential impact of future LULC changes.

\section{MATERIALS AND METHODS}

\subsection{Study Area}

Kelantan is located in the East Coast of Peninsular Malaysia, between latitudes $4^{\circ} 40^{\prime}$ and $6^{\circ} 12^{\prime} \mathrm{N}$ and between longitudes $101{ }^{\circ} 20^{\prime}$ and $1020^{\prime}$ ' E (Figure 1). The total area of this state is approximately $15,100 \mathrm{~km}^{2}$, with a population of 1.7 million people. Kota Bharu is the capital city and major urban center of the state. It is located in the northern region of Kelantan. It has a typical tropical climate system with annual precipitation and mean temperature of $2500 \mathrm{~mm}$ and $27.5^{\circ} \mathrm{C}$, respectively (Tan et al. 2018).

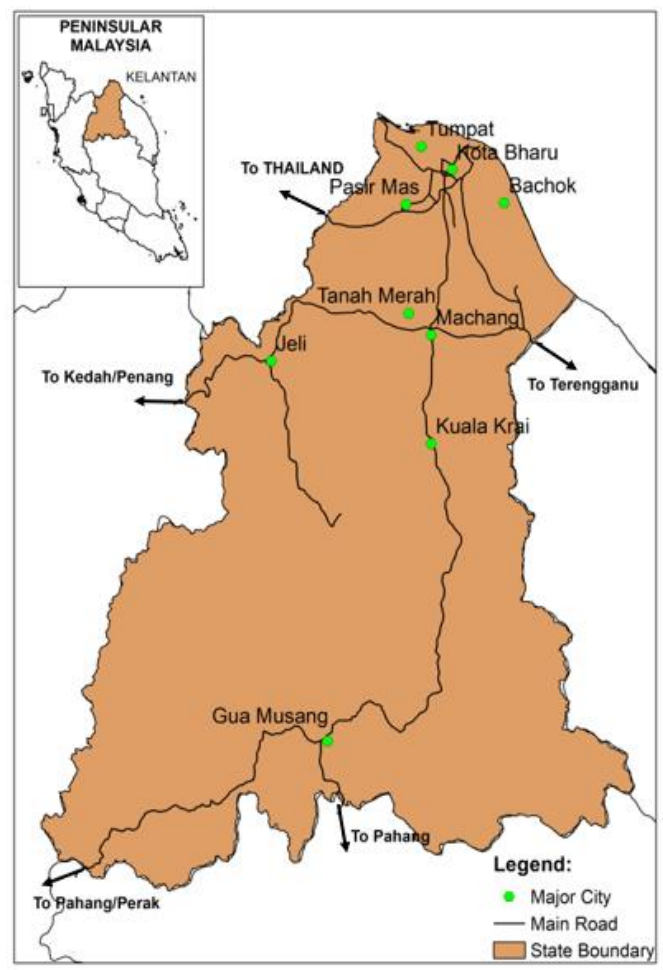

Figure 1. The Study Area

\subsection{Data Sources}

The research was conducted using spatial datasets obtained from Malaysia Geographical Information System (MyGIS,
2018). All spatial datasets were projected into the same coordinate system, Kertau RSO Malaya, in meters.

Euclidean distances were generated from the city centers, major roads, education institutions, health facilities, employment centers, and developed areas in ArcMap 10.4, and then clipped to Kelantan's boundary files (Table 1).

Table 1. Spatial datasets

\begin{tabular}{|l|l|c|}
\hline \multicolumn{1}{|c|}{ Class } & \multicolumn{1}{c|}{ Data Type } & \multicolumn{1}{c|}{ Year } \\
\hline Land use & Shapefile (polygon) & $\begin{array}{c}1991,2000,2008, \\
2013\end{array}$ \\
\hline Major roads & Shapefile (line) & 2015 \\
\hline City centers & Shapefile (point) & 2015 \\
\hline $\begin{array}{l}\text { Education } \\
\text { institutions }\end{array}$ & Shapefile (polygon) & 2015 \\
\hline Health facilities & Shapefile (polygon) & 2015 \\
\hline $\begin{array}{l}\text { Employment } \\
\text { Centers }\end{array}$ & Shapefile (point) & 2015 \\
\hline Developed Areas & Shapefile (polygon) & 2015 \\
\hline
\end{tabular}

Most of the data that used as factors influencing the LULC changes are collected in 2015. As the major facilities (e.g. major roads, education institutions and health facilities) have only small changes between 2008 and 2015 in Kelantan, therefore, we assumed that the impact on future LULC simulation can be neglected.

\subsection{CA-Markov Model}

Cellular Automata - Markovian (CA-Markov) model, embedded in the Idrisi Kilimanjaro software, was used to model and predict the land use pattern of the study area for the year 2025 . All of the different datasets used were pre-processed to have the same spatial resolution $(30 \mathrm{~m} \times 30 \mathrm{~m})$. Additionally, the land cover maps used also had the same values and corresponding legends and a background value of zero.

In setting up the CA-Markov model, the 1991 and 2000 land use maps were used as the base maps. The two land use maps were reclassified into seven land cover class categories that can be applied in the Soil and Water Assessment Tool (SWAT) modelling (Tan et al., 2019) in the near future. The transition matrix file was calculated using the Markov model in Idrisi Kilimanjaro software, where it records the number of cells that are expected to change from one land use class to another in a given period in the future.

Transitional area matrices were generated based on the historical LULC information from 1991-2000, 1991-2008 and 1991-2013 to explore how each land use was projected to change. Detailed process has been presented in Figure 2.

In this study, multi-criteria evaluation (MCE) and analytic hierarchy process (AHP) were applied to generate transition potential maps. The AHP method was applied to determine the weights of driving factors with the use of pairwise comparison matrix (Beynon, 2002; Hossain et al., 2014). The transition potential maps indicate the possibilities of a pixel to turn from one class to another or remain unchanged. 


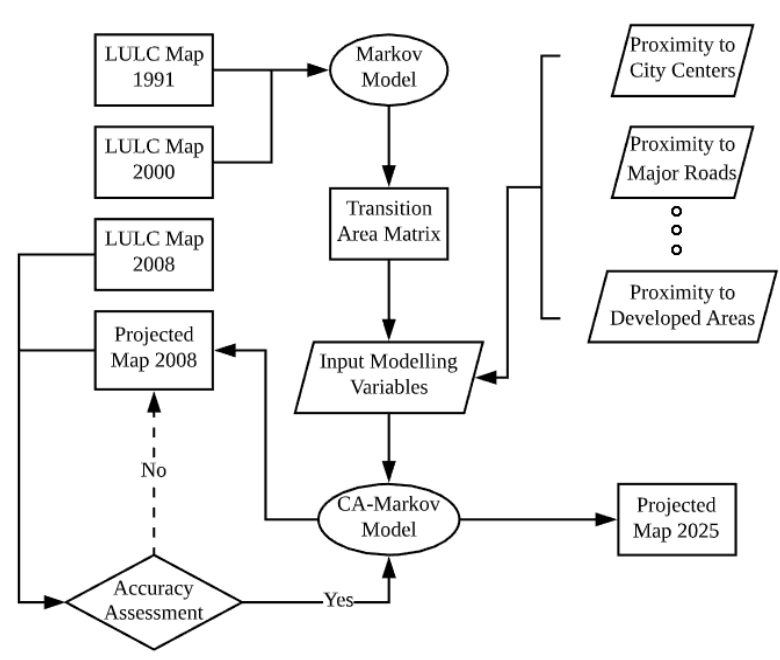

Figure 2. Land use land cover simulation process

\section{RESULTS AND DISCUSSIONS}

\subsection{LULC Change}

Based on Table 2, a significant increasing trend was found for the built-up area, while a consistent decreasing trend of forest area. The built-up area increased by $110.93 \mathrm{~km}^{2}$ from $31.41 \mathrm{~km}^{2}$ $(0.21 \%)$ in 1991 to $142.34 \mathrm{~km}^{2}(0.93 \%)$ in 2013 . However, forest area suffered loss by $1531.67 \mathrm{~km}^{2}$ from $10715.90 \mathrm{~km}^{2}$ (71.32\%) in 1991 to $9184.23 \mathrm{~km}^{2}(61.39 \%)$ in 2013.

Table 2. LULC distribution in Kelantan from 1991 to 2013

\begin{tabular}{|l|c|c|c|c|}
\hline $\begin{array}{c}\text { LULC } \\
\text { Class }\end{array}$ & $\begin{array}{c}\mathbf{1 9 9 1} \\
\left.\mathbf{k m}^{\mathbf{2}}\right)\end{array}$ & $\begin{array}{c}\mathbf{2 0 0 0} \\
\left.\mathbf{( k m}^{\mathbf{2}}\right)\end{array}$ & $\begin{array}{c}\mathbf{2 0 0 8} \\
\left(\mathbf{k m}^{\mathbf{2}}\right)\end{array}$ & $\begin{array}{c}\mathbf{2 0 1 3} \\
\left(\mathbf{k m}^{\mathbf{2}}\right)\end{array}$ \\
\hline Built-up & 31.41 & 76.11 & 114.33 & 142.34 \\
\hline Forest & $\begin{array}{c}10715.9 \\
0\end{array}$ & 10156.24 & 9485.97 & 9184.23 \\
\hline Oil Palm & 640.44 & 836.01 & 1314.06 & 1522.34 \\
\hline $\begin{array}{l}\text { Others } \\
\text { Agriculture }\end{array}$ & 630.47 & 570.49 & 1071.78 & 845.83 \\
\hline Paddy & 764.39 & 891.93 & 598.49 & 762.97 \\
\hline Rubber & 2029.14 & 2284.89 & 2169.84 & 2349.04 \\
\hline $\begin{array}{l}\text { Water } \\
\text { Body }\end{array}$ & 214.31 & 210.44 & 271.60 & 215.78 \\
\hline
\end{tabular}

Northern part of Kelantan contributes significant increase of the total built-up area in the whole state due to existence of administrative city (Kota Bharu) and neighbouring cities (Tumpat, Bachok, and Pasir Mas). This region is a favourable choice of people to stay that connecting these four cities. While in the southern part of Kelantan suffers immense loss of forest area due to the expansion of oil palm planting.

\subsection{Markov Model}

Markov model calculates a transition probability matrix that evaluate the ability of a class to convert into another class. The matrix was computed based on LULC transition from 1991 to 2000 (Table 3) and 1991 to 2008 (Table 4) to show how each land use class was projected. These transition probability matrixes will then incorporate into CA-Markov model.
Table 3. Transition probability matrix 1991-2000

\begin{tabular}{|l|l|l|l|l|l|l|l|}
\hline & C1 & C2 & C3 & C4 & C5 & C6 & C7 \\
\hline Class 1 & 0.43 & 0.03 & 0.09 & 0.23 & 0.12 & 0.02 & 0.08 \\
\hline Class 2 & 0.00 & 0.78 & 0.06 & 0.02 & 0.00 & 0.14 & 0.00 \\
\hline Class 3 & 0.01 & 0.22 & 0.63 & 0.02 & 0.00 & 0.12 & 0.00 \\
\hline Class 4 & 0.03 & 0.04 & 0.02 & 0.37 & 0.31 & 0.14 & 0.09 \\
\hline Class 5 & 0.01 & 0.02 & 0.00 & 0.22 & 0.56 & 0.13 & 0.06 \\
\hline Class 6 & 0.02 & 0.13 & 0.07 & 0.04 & 0.11 & 0.62 & 0.01 \\
\hline Class 7 & 0.01 & 0.01 & 0.03 & 0.18 & 0.19 & 0.17 & 0.41 \\
\hline
\end{tabular}

*Class $1 / \mathrm{C} 1=$ Built-up; Class $2 / \mathrm{C} 2=$ Forest; Class $3 / \mathrm{C} 3=$ Oil Palm; Class 4/C4 = Others Agriculture; Class 5/C5 = Paddy; Class 6/C6 = Rubber; Class 7/C7 = Water Body.

Table 4. Transition probability matrix 1991-2008

\begin{tabular}{|c|c|c|c|c|c|c|c|}
\hline & C1 & C2 & C3 & C4 & C5 & C6 & C7 \\
\hline Class 1 & 0.43 & 0.05 & 0.06 & 0.37 & 0.03 & 0.04 & 0.03 \\
\hline Class 2 & 0.00 & 0.74 & 0.11 & 0.04 & 0.00 & 0.10 & 0.01 \\
\hline Class 3 & 0.01 & 0.10 & 0.69 & 0.04 & 0.00 & 0.16 & 0.00 \\
\hline Class 4 & 0.06 & 0.03 & 0.02 & 0.50 & 0.18 & 0.15 & 0.06 \\
\hline Class 5 & 0.02 & 0.01 & 0.00 & 0.34 & 0.47 & 0.12 & 0.05 \\
\hline Class 6 & 0.02 & 0.08 & 0.12 & 0.14 & 0.04 & 0.57 & 0.02 \\
\hline Class 7 & 0.01 & 0.07 & 0.03 & 0.20 & 0.09 & 0.21 & 0.39 \\
\hline
\end{tabular}

${ }^{*}$ Class $1 / \mathrm{C} 1=$ Built-up; Class $2 / \mathrm{C} 2=$ Forest; Class $3 / \mathrm{C} 3=$ Oil Palm; Class 4/C4 = Others Agriculture; Class 5/C5 = Paddy; Class 6/C6 = Rubber; Class 7/C7 = Water Body.

\subsection{Factors and Suitability Parameters}

Factors influencing land use land cover changes is important in simulating future LULC pattern. Due to the variety of factors, it is necessary to figure out weights or relative importance of each identified factor, which is crucial contribution in the study. Table 5 shows weights of factors used in the LULC model.

Table 5. Weights of each factors used in the study

\begin{tabular}{|l|c|}
\hline \multicolumn{1}{|c|}{ Factor } & Weights \\
\hline Proximity to educational institutions & 0.06 \\
\hline Proximity to employment centers & 0.19 \\
\hline Proximity to developed areas & 0.10 \\
\hline Proximity to health facilities & 0.04 \\
\hline Proximity to major roads & 0.35 \\
\hline Proximity to major towns & 0.26 \\
\hline Consistency ratio & 0.08 \\
\hline
\end{tabular}

Weights were determined based on their influence on LULC development with the basis of interview undertaken with five local planners, who directly involved in land use planning in the study area (Samat, 2009). These weights were held constant throughout the simulation. The parameters to define the suitability of a cell to change from one type of land use to another were defined to represent the possibilities of the land to be occupied by each of the other land uses. 
These parameters were assigned to the variables of built-up, proximity to educational institutions, proximity to health facilities, proximity to major roads, and proximity to major towns. The suitability parameters for the variables of built-up was defined as zero for not suitable and one for suitable (Figure 3). The suitability parameters proximity to educational institutions, proximity to health facilities, proximity to major roads, and proximity to major towns were assigned on a scale of 0 to 4 to represent a low and high preferences, respectively (Figure 4).

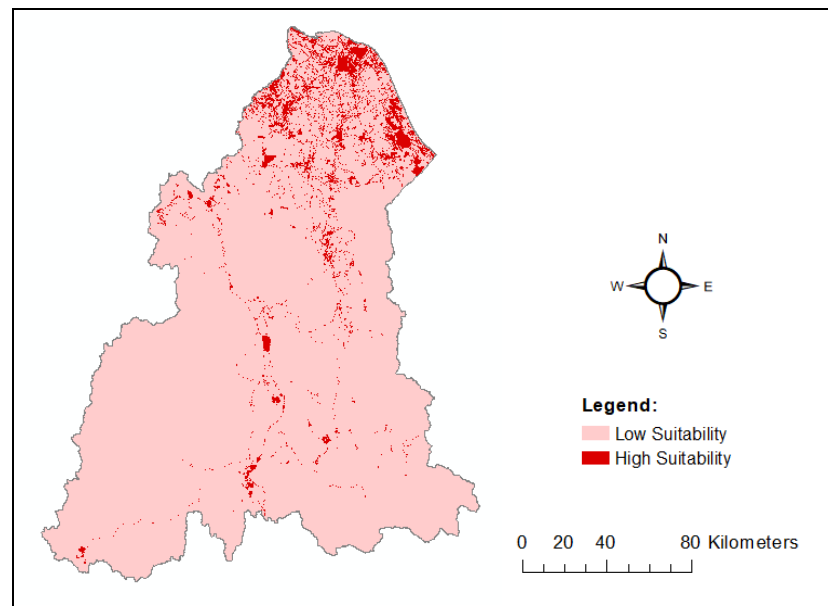

Figure 3. Suitability parameters: Red Cells are suitable for urban development, and Pink Cells are not suitable for urban development.

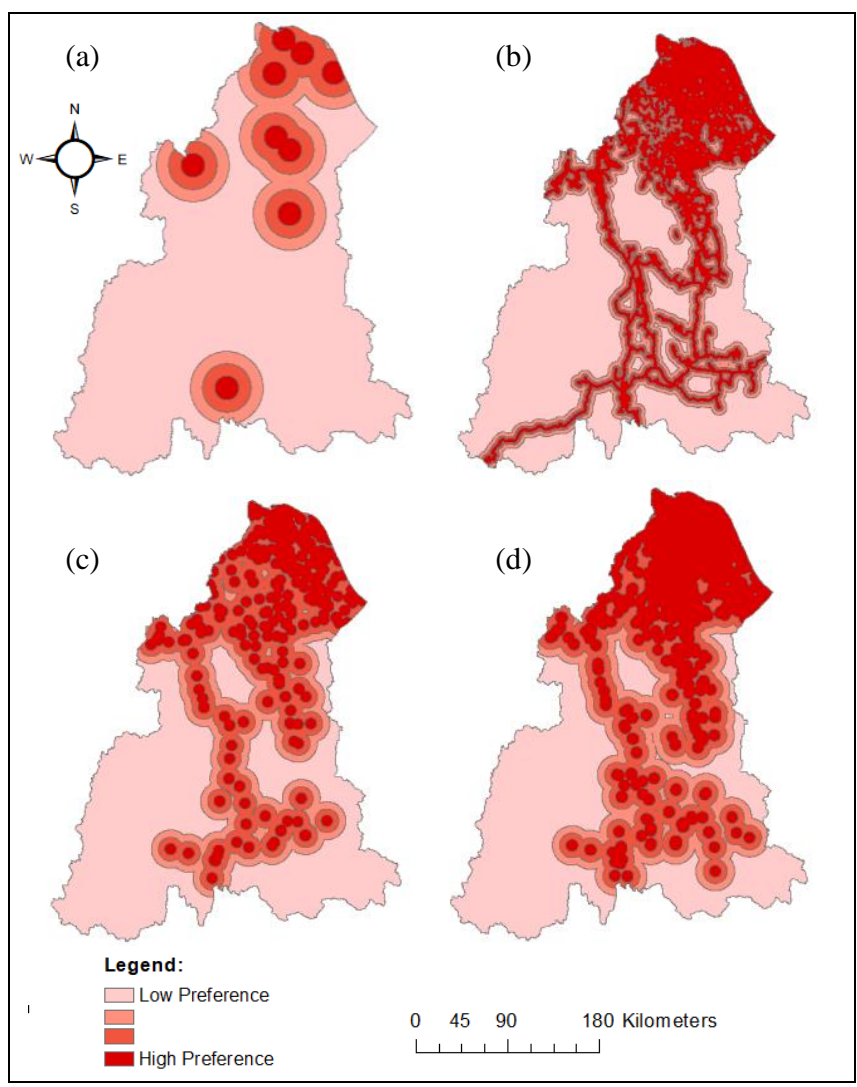

Figure 4. Suitability parameters: (a) proximity to major towns (m); (b) proximity to major roads (m); (c) proximity to educational institutions $(\mathrm{m})$; and $(\mathrm{d})$ proximity to health institutions.
Land use 2000 was used as initial state of the model using transition probability matrix of 1991-2000 (Table 3), and suitability parameters from Figures 3 and 4 were used to project LULC pattern of 2008 (Figure 5). The output produced was validated using actual land use data of 2008 .

The accuracy of the model is $78.57 \%$, where the result was within the tolerance, then we used the model to generate the simulation LULC maps of 2025 (Figure 6) using transition probability matrix of 1991-2008 (Table 4), and suitability parameters from Figure 4 and Figure 5.

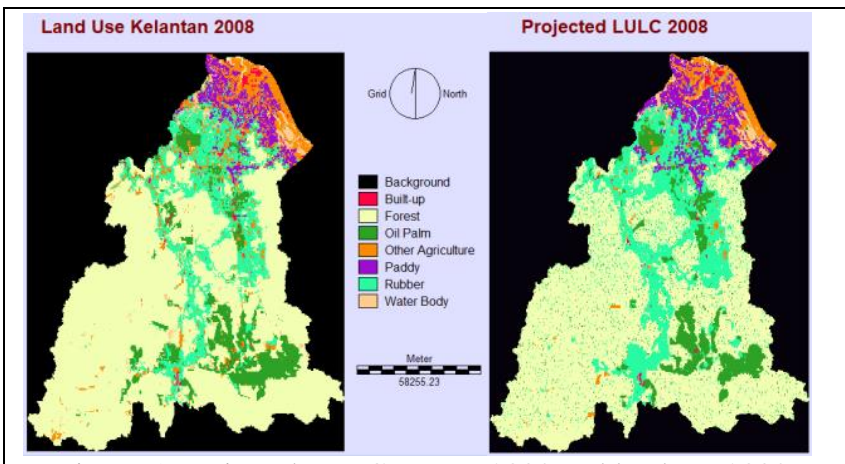

Figure 5. Projected LULC pattern 2008 and land use 2008.

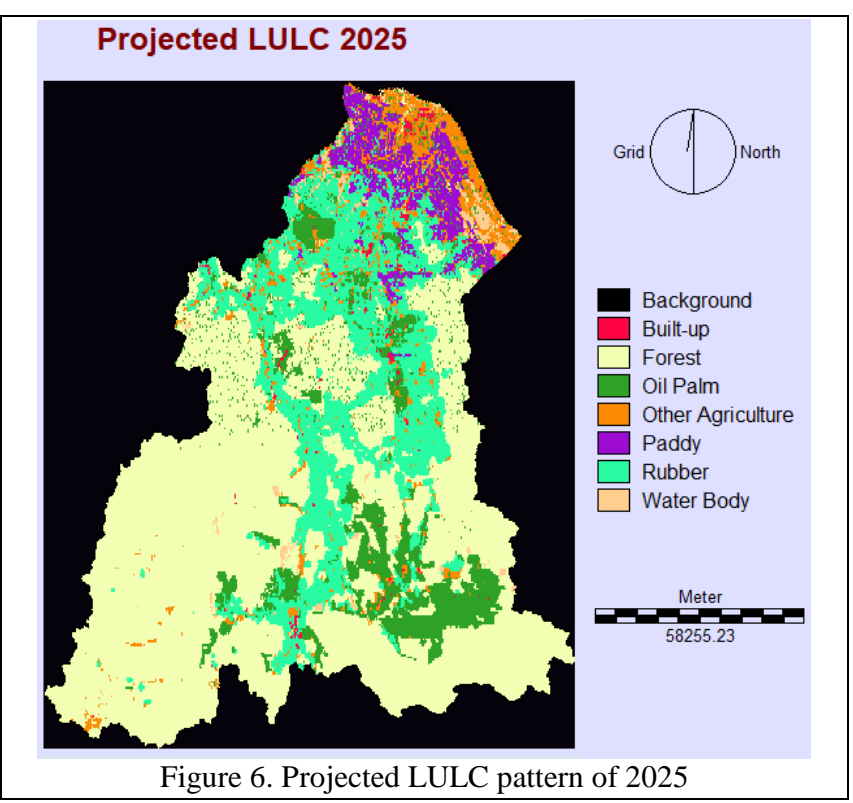

\subsection{Accuracy Assessment}

An accuracy assessment was conducted by comparing the projected 2008 LULC and the actual land use map obtained from MyGIS (2018). Table 6 shows the results of accuracy assessment for each class of projected LULC year 2008 validation. The projected LULC 2008 have $78.57 \%$ match with the actual land use 2008. With this confidence of model accuracy, we assumed that the projected LULC 2025 will have similar accuracy as the model used same suitability parameters, weightage of factors and transition probability matrix that capture changes from year 1991-2008. The transition probability matrix captured possibilities of a class to convert into another class within the period, and by using 2008 as the base map, the model will simulate the next 17 years projected map (projected LULC 2025). 
Table 6. Accuracy assessment for each categories of simulated LULC 2008

\begin{tabular}{|c|c|}
\hline Category & KIA \\
\hline 1 & 0.6327 \\
\hline 2 & 0.7888 \\
\hline 3 & 0.7229 \\
\hline 4 & 0.6264 \\
\hline 5 & 0.7580 \\
\hline 6 & 0.6884 \\
\hline 7 & 0.6808 \\
\hline Overall Kappa $=$ & 0.7857 \\
\hline
\end{tabular}

*KIA = Kappa Index of Agreement, Category 1 = Built-up; Category 2 = Forest; Category 3 = Oil Palm; Category $4=$ Others Agriculture; Category 5 = Paddy; Category 6 = Rubber; Category $7=$ Water Body

\subsection{Future Land Use Land Cover}

The area size of each projected LULC is shown in Table 7. In simulated LULC 2008, built-up area is projected to grow at the major cities in the northern Kelantan while in simulated LULC 2025 , built-up area is expected to grow at the major cities in the central and southern Kelantan. The simulated LULC 2025 also shown that sprawl development is began to exist, which should alert urban planners to plan the development in Kelantan.

Table 7. Projected LULC area year 2008 and 2025

\begin{tabular}{|l|c|c|}
\hline LULC Class & $\begin{array}{c}\mathbf{2 0 0 8} \\
\mathbf{( k m}^{\mathbf{2}}\end{array}$ & $\begin{array}{c}\mathbf{2 0 2 5} \\
\mathbf{( k m}^{\mathbf{2}}\end{array}$ \\
\hline Built-up & 114.27 & 181.69 \\
\hline Forest & 9535.46 & 8548.20 \\
\hline Oil Palm & 1308.24 & 2142.48 \\
\hline $\begin{array}{l}\text { Others } \\
\text { Agriculture }\end{array}$ & 1007.94 & 1320.18 \\
\hline Paddy & 770.87 & 693.44 \\
\hline Rubber & 2210.60 & 3076.24 \\
\hline Water Body & 327.63 & 344.45 \\
\hline
\end{tabular}

On the other hand, others agriculture is projected to grow along the coastal of northern Kelantan in both the 2008 and 2025 LULC maps. This might be due to people began to plant vegetables and fruit on their own land for their own purposes.

In general, deforestation mainly found in the southern part of Kelantan in both the 2008 and 2015 maps (Figure 6). One of the possible reasons for this might be due to the agricultural expansion of the rubber and oil palm plantations. Loss of forest area might give bad impact to environment even though rubber and oil palm are benefit to Kelantan's economy. Urban planners should prepare alternative action to avoid environmental problem event to occur in Kelantan.

\section{CONCLUSION}

The study projected the future LULC of Kelantan, Malaysia, using the CA-Markov model. In the past few decades, major changes of Kelantan were found for the increment of built-up and agriculture area, and reduction in forest area. The accuracy of the CA-Markov model is $78.57 \%$, which is then used to simulate LULC pattern of 2025. Agricultural area was increased significantly in 2025 , especially the oil palm plantation. By contrast, a significant decreasing trend of forest was found. Built-up area especially in the northern part of Kelantan will be expanded with a low rate, together with an existence of urban sprawl in the central part of Kelantan.

Understanding of the changes in LULC pattern and urban development of any area over time is important for effective land use management and sustainable urban planning. The CAMarkov model is recommended as an appropriate tool for further research of the complexity of urban development and LULC change. Future work will incorporate the projected map into SWAT to study the impact of LULC on water resources and disasters in Kelantan.

\section{ACKNOWLEDGEMENTS}

This research was funded by the Ministry of Higher Education (MoHE) Malaysia through the Fundamental Research Grant Scheme (FRGS) grant number 203/PHUMANITI/6711709 and 203/PHUMANITI/6711695. Also, this research was funded by the Ministry of Higher Education (MoHE) Malaysia under the Newton-NERC grant number 203/PHUMANITI/6780001.

\section{REFERENCES}

Batty, M., \& Xie, Y., 1994. From cells to cities. Environment and Planning B: Planning and Design, 21(7), S31-S48. https://doi.org/10.1068/b21S031

Beynon, M., 2002. DS/AHP method: a mathematical analysis, including an understanding of uncertainty. European Journal of Operational Research, 140, 148-164.

Chu, L., Sun, T., Wang, T., Li, Z. \& Cai, C., 2018. Evolution and prediction of landscape pattern and habitat quality based on CA-Markov and InVEST model in Hubei section of Three Gorges Reservoir Area (TGRA). Sustainability, 10(11), 3854.

Hossain, M. F., Adnan, Z. H. \& Hasin, M. A. A., 2014. Improvement in weighting assignment process in Analytic Hierarchy Process by introducing suggestion matrix and Likert scale. International Journal of Supply Chain Management, 3(4), 91-95.

Jodar-Abellan, A., Valdes-Abellan, J., Pla, C. \& GomarizCastillo, F., 2019. Impact of land use changes on flash flood prediction using a sub-daily SWAT model in five Mediterranian ungauged watersheds (SE Spain). Sci Total Environ, 657, 15781591. Doi:10.1016/ j.scitotenv.2018.12.034

Li, S., Yang, H., Lacayo, M., Liu, J. \& Lei, G., 2018. Impacts of Land-Use and Land-Cover Changes on Water Yield: A Case Study in Jing-Jin-Ji, China. Sustainability, 10(4), 960. 
Liping, C., Yusun, S. \& Saeed, S., 2018. Monitoring and predicting land use and land cover changes using remote sensing and GIS techniques - a case study of a hilly area, Jiangle China, Plos One, 13(7): e0200493. https://doi.org/10.1371/journal.pone.0200493

MyGIS, 2018. Malaysia Geographical Information System, Malaysia Open Sources Data. www.mygis.com.my (1 June 2018)

Omar, N. Q., Ahamad, M. S. S., Wan Hussin, W. M. A., Samat, N. \& Ahmad, S. Z., 2014. Markov CA, multi regression and multiple decision making for modeling historical changes in Kirkuk City, Iraq, Journal of the Indian Society of Remote Sensing, 42 (1), 165-178.

Narany, T. S., Aris, A.Z., Sefie, A. \& Keesstra, S., 2017. Detecting and predicting the impact of land use changes on groundwater quality, a case study in Northern Kelantan, Malaysia. Science of The Total Environment, 599-600, 844853.

Samat, N., 2009. Integrating GIS and CA-Markov model in evaluating urban spatial growth, Malaysian Journal of Environmental Management, 10(1), 83-100.

Samat, N. \& Mahamud, M. A., 2018. Urbanisation in the George Town conurbation and its impact to the environment. International Journal of Environmental Engineering, 9(3-4), 240-253.

Sharma, R., Rimal, B., Baral, H., Nehren, U., Paudyal, K., Sharma, S., Rijal, S., Ranpal, S., Acharya, R.P., Alenazy, A.A. \& Kandel, P., 2019. Impact of land cover change on ecosystem services in a tropical forested landscape. Resources, 8(1), 18

Tan, M. L., Gassman, P. W., Srinivasan, R., Arnold, J. G., \& Yang, X., 2019. Review of SWAT studies in Southeast Asia: applications, challenges, and future directions. Water, 11(5), 914.

Tan, M. L., Ibrahim, A. L., Yusop, Z., Chua, V. P. \& Chan, N. W., 2017. Climate change impacts under CMIP5 RCP scenarios on water resources of the Kelantan River Basin, Malaysia. Atmospheric Research, 189, 1-10.

Tan, M. L., Ibrahim, A. L., Yusop, Z., Duan, Z. \& Ling, L., 2015. Impacts of land-use and climate variability on hydrological components in the Johor River basin, Malaysia. Hydrological Sciences Journal, 60(5), 873-889.

Tan, M. L., Samat, N., Chan, N. W. \& Roy, R., 2018. hydrometeorological assessment of three gpm satellite precipitation products in the Kelantan River Basin, Malaysia. Remote Sensing, 10(7), 1011.

Wang, R., Hou, H. \& Murayama, Y., 2018. Scenario-based simulation of tianjin city using a Cellular Automata-Markov model. Sustainability, 10(8), 2633. 